\title{
Housing for Refugees in Sweden: Top-Down Governance and its Local Reactions
}

\author{
Henrik Emilsson ${ }^{1} \cdot$ Klara Öberg $^{2}$ (D
}

Accepted: 3 June 2021/Published online: 29 June 2021

(C) The Author(s) 2021

\begin{abstract}
In this article, we investigate local level reactions to the top-down state steering for the housing of refugees in Sweden. We especially reflect on events after the increased refugee reception in Sweden in 2015 and the introduction of a Settlement Act in 2016 which made it mandatory for municipalities to receive a specific number of refugees and organise accommodation. This has resulted in a wide array of housing situations for refugees concerning standard, costs and temporary solutions. A multi-level governance framework from on central government steering perspective is applied. We argue that the modified legislation can be understood as a change in governance throughout the years - from persuasion to economic incentives and, finally, to coercive methods. Sweden is a country that has distinguished itself as one refraining from particularity and continuing to work towards equality between newcomers and citizens. In relation to recent legal and political developments, we identify a change - a paradoxical change, as governance for the more-equal reception of refugees in Sweden seems to lead to increased inequalities for refugees on the local level.
\end{abstract}

Keywords Housing $\cdot$ Refugees $\cdot$ Settlement act $\cdot$ Multi-level governance $\cdot$ Local level

\section{Introduction}

Housing for refugees has grown into one of the most urgent integration policy issues in Sweden. In response to the increased number of refugees in 2015 , the government introduced several legal measures — including a Settlement Law (2016:38) —

Klara Öberg

klara.oberg@hh.se

Henrik Emilsson

henrik.emilsson@mau.se

1 Department of Global Political Studies, Malmö University, 20506 Malmö, Sweden

2 School of Health and Welfare, Halmstad University, Box 823, 30118 Halmstad, Sweden 
designed to regulate the dispersal to local municipalities of refugees residing in stateprovided accommodation. Under this law, the municipalities are obliged to receive and organise housing for such refugees. The law can thus be understood as a way to nationally disperse refugee settlement and make it more difficult for free settlement, as refugees who stay in their own accommodation during their asylum period are not entitled to housing through the Settlement Law. The relatively high intake of refugees, combined with housing shortages and the new governance of refugee housing, has changed the relations between the levels of government and brought about new refugee housing solutions at the local level. Where earlier discussions and reports on housing for refugees in Sweden were mostly about housing in relation to ethnic and socioeconomic segregation (see, for example, the Integration Board, 2001, 2003 reports on housing), policy discussions today are framed as a competition for access to housing and growing local resistance to the settlement of refugees. Housing for refugees must be understood from a multilevel governance perspective. It is the state which decides on migration policies and accepts refugees. However, it is the municipalities which are responsible for providing housing for its residents in accordance with the Municipal Act (1991: 900) and Social Services Act (2001: 453). Where previous studies of refugee settlement focused on the discourses (Borevi and Bengtsson, 2015; Myrberg, 2017), we concentrate on actual state policy measures and their local consequences. Thus, we don't study the arguments for, or against, state policies formulated on the local level. Our interest is on how local governments react and implement state policies.

In this article, we investigate reactions to the top-down state steering for the housing of refugees on the local level. Over time, top-down steering has limited the discretion of local governments. Local discourses on refugee settlement, structural factors such as housing opportunities and the size and location of municipalities, as well as administrative categorisations at the local level, are all contributing to a differentiation of housing standards and terms for refugees, one which is challenging both the longstanding integration policy principle of equal rights and the idea of a universal welfare state as a cornerstone in the socio-democratic welfare-state model.

Through examples of local reactions to the settlement law in two municipalities in Scania — Malmö and Eslöv — we argue that one effect of increased national governance is, in fact, increased local diversification, which is contrary to the intentions of national governance. The coercive aspects of the settlement law contributed to changes in local housing policies to more temporary housing arrangements for refugees and to a differentiation of services between different categories of refugees.

The question of whether we are witnessing a contemporary national or a local turn has been debated elsewhere (Emilsson, 2015). Our examples show that this issue is more complex - while there is arguably a national turn through coercive governance in Sweden, we additionally observe local reactions to that governance. These reactions, in their turn, affect national governance and political integration goals - effects that have an impact on how national law is interpreted locally. We further reflect on how local reactions result in a new categorisation of a particular group of refugees and their access to specific housing, which creates a conflicting situation when different categories and their needs are pitted against each other at the local level. Through this example of increased national governance, we see a paradoxical result in the form of increased inequality at the local level. 
The article is set out as follows. Firstly, we present prior relevant research related to refugees and housing issues. Secondly, we present our method and theoretical perspectives. Thirdly, we examine the development of housing politics in Sweden. Fourthly, we explain the transition of refugee settlement governance in Sweden before, finally, discussing our observations in relation to local reactions to the Settlement Law in the municipalities of Malmö and Eslöv and the effects that they have on local governance and differentiation.

\section{Prior Research on the Dispersal of and Access to Housing for Refugees in Sweden}

The dispersal of asylum-seekers and refugees is an issue at the EU level as well as in most individual member states with a considerable number of asylum applications. Even though Sweden, traditionally, has preferred intergovernmental cooperation over supranationalism at the EU level, it has been one of the countries the most keen to advocate for a common European asylum policy in order to 'spread the burden' (Spehar, 2014). Many countries also have housing strategies based on the idea that the dispersal of asylum-seekers and refugees within countries is important and that policies should be in place to realise that aim (Hamann and El-Kayed, 2018; Larsen, 2011; Stewart, 2011). The idea of counteracting ethnic clustering seems to be a key component of dispersal policies (Andersson, 2003). Other reasons are to spread the costs, to facilitate the effective use of housing capacity and to stimulate positive social interaction.

Previous studies on housing for refugees in Sweden has focused on a diverse range of issues. Some are interested in the effects of housing and settlement policies on the socio-economic integration of refugees. Most results indicate that the steering of refugee settlement is bad for integration (Åslund and Rooth, 2007; Edin et al., 2003; Zenou et al., 2006). A recent study looking specifically at the employment probabilities for refugees who stayed in state-funded accommodation versus those who found their own private accommodation (eget boende or $\mathrm{EBO}$ ) during the asylum period, revealed substantial differences, in which the latter group perform better (Bevelander et al., 2019). A report on Swedish integration policies for refugees investigated the effects of the 2016 policy on mandatory refugee reception by Swedish municipalities (Osanami Törngren and Emilsson, 2018) and showed that the policy resulted in an equal reception across municipalities.

Other studies are closer to the subject of this article and deal with the governance of refugee settlement and its local consequences. Aflaki and Freise (2019) study the effects, at the local level, of policy changes in the settlement of unaccompanied minors in Germany and Sweden. In Sweden, a new state compensation system for unaccompanied minors in 2017 forced local municipalities to implement policy innovations and new forms of cooperation with civil-society organisations. Myrberg (2017) studied the relationship between the state and local municipalities in Denmark (Åarhus) and Sweden (Malmö). He describes how both municipalities in the mid-1990s lobbied the state for a relief from refugee settlement. While the Danish government responded with tougher migration policies and the restriction of individual autonomy in the 
housing market, the Swedish state turned a deaf ear to Malmö's concerns. Myrberg concluded that generous migration policies in combination with respect for the individual autonomy of newcomers have created a difficult situation in terms of housing and introduction in Malmö. An article by Borevi and Bengtsson (2015) provides us with some clues as to why the Swedish government did not respond to the pleas from Malmö. They identify three sets of arguments which a state can use to legitimise the steering of newcomers' settlement: (1) the legal status of the new arrivals (legal status argument); (2) the special needs and limited resources of newcomers (resource argument); and (3) the prioritisation of collective political goals about social environments in the integration of newcomers (neighbourhood argument). Borevi and Bengtsson conclude that steering newcomers' settlement in Sweden is difficult due to the illegitimacy of the legal status arguments which deny refugees (and asylum-seekers) the same rights as citizens in the housing market. This strong normative position of individual autonomy in the housing market may, they argue, produce a path-dependent discursive lock-in that hinders settlement reforms that violate this principle.

\section{Theoretical Framework}

In order to understand local housing provisions for refugees, we are applying a multi-level governance framework inspired by Etzioni (1975). He wanted to understand how subordinate actors in complex organisations behave in relation to another actor's power and how those in power make other actors follow their directives. The political scientist Vedung (2009) transferred this idea to the policy evaluation literature. This framework provides a different perspective on multi-level governance compared to a more traditional frame analysis. Where a frame analysis investigates whether policies align or not between government levels (Dekker et al., 2015), our framework looks at governance techniques and policy instruments (see Emilsson, 2015 for a more in-depth discussion of the theoretical framework). A central issue in Etzioni's model is compliance. The state wants local governments to comply in order to deliver on the policies and political goals which the government has drawn up. As we saw in the literature review, the state has different ideas on how it wants to settle refugees and uses different instruments to realise them. In short and following Etzioni's model, the state can use three different instruments to realise their policy ambitions: coercive, remunerative and normative (1975: 5). In this article, we call the instruments coercive, economic and persuasive.

Coercive instruments can be the laws and regulations imposed by the state through decisions in parliament or, in some cases, decided by central governmental agencies. The municipalities are obliged to act in accordance with them. Reallocations of authority between territorial levels can also be seen as a coercive instrument (Porter and Olsen, 1976). Economic instruments often take the form of state funding for targeted measures at the local level implemented by local government or nongovernmental organisations. Persuasive instruments involve attempts to influence local governments by conviction, persuasion or knowledge. These instruments are not mutually exclusive but can, as in the case of refugee housing, be combined to enforce compliance at the local level. 


\section{Method and Material}

The material for this article was collected through interviews, local, regional and national policy documents, reports and statistics. The main location is Malmö in Scania, in the south of Sweden, with a population of around 340,000 inhabitants. We also conducted interviews in Eslöv, a smaller and more rural municipality within commuting distance of Malmö. The reason for this was partly that many asylumseekers and refugees who arrived in Scania passed through Malmö and were registered at the Swedish Migration Agency there, although this changed after the Swedish government introduced the temporary law on border control to diminish the numbers of arriving refugees. This was the case for most of the people whom we interviewed in Eslöv. In relation to settlement, there were, however, different examples of how they had arrived in Eslöv - either through self-settlement or municipality placement. Another reason for interviews with refugees and officials in Eslöv was to expand our knowledge on local variation in the reception of refugees. The text should not, however, be understood as a comparison of the reception of refugees in the two municipalities as it merely focuses on issues of accommodation.

For the interviews, we used guides with open-ended questions. The selection of interviewees was made according to two different principles. In a total of 14 interviews at the national, regional and local level, we identified key officials in relation to our core issues on housing and refugees. We interviewed a total of 20 refugees who were resident in the municipalities of Malmö and Eslöv, selected according to age, gender and nationality in order to reach a more diverse representation of experiences.

\section{The Swedish Housing Context}

The Swedish housing regime rests on four overlapping pillars: (1) a universal housing policy, (2) municipal housing companies, (3) an integrated rental market and (4) a system of collectively negotiated use-value rents (Bengtsson, 2013; Grander, 2018). A universal housing policy is aimed at all citizens without means testing. Municipal housing companies, owned by local municipalities, are an important provider of housing. The application of these four pillars means that Sweden does not apply to models of social housing (Granath Hansson and Lundgren, 2019) such as the British particularistic model where the state provides specific housing for low-income households. Ideally, vulnerable populations such as refugees should therefore be treated in the same way as the general population when it comes to housing. The universal approach has, however, increasingly been supported by a secondary housing market (Grander, 2018). Individuals who are incapable of finding housing of their own, for example, due to substance abuse or mental illness, are provided with apartments that municipalities rent from private and public housing companies.

A starting point for understanding housing policy in Sweden is that housing is considered a social right. The goal is to create conditions for everyone to live in good housing at a reasonable cost. The realisation of this objective requires active efforts by the municipalities. According to the Act on Municipal Housing Responsibility (2000: 1383), each municipality must plan for its housing capacity. Up until the early 1990s, the state played an important role in supporting local municipalities to secure housing. 
Through the Million Programme, between 1965 and 1974 one million dwellings were built. They were state-financed but organised by local governments, who also controlled and provided access to the apartments. Well into the 1980s, housing construction subventions remained the third-largest post in the state budget. However, in the early 1990s, this form of state support for local housing provision ended. Other changes that fundamentally altered the framework for access to housing was the decreased housing allowance for tenants (Sahlin, 2004). In relation to changed national housing policies, the discourse on homelessness changed (Sahlin, 2004). Homelessness became more of an issue for social services and related to a person's inability to maintain housing due to social issues such as drug abuse or mental illness. In a way, the empirical situation supported the discourse.

Starting from the mid-2000s, however, a new structural housing situation emerged. Figure 1 shows the number of new dwellings and the population increase between 1990 and 2016. We can see that the number of new dwellings decreased in the early 1990s and has remained quite low ever since. The recent trend is for construction to increase somewhat. From the mid-2000s, the gap between the new dwellings and the population increase became much wider and has remained so throughout the last decade. The population increase was due to two combining factors: an increasing number of refugees and family reunifications and immigration from new EU member states.

Due to a shortage of housing, a new form of structural homelessness developed in parallel to social homelessness. Today the National Board of Housing, Building and Planning (2019) speaks of a quite dramatic shortage of housing in Swedish municipalities. A majority - 240 of 290 - of the municipalities indicate general housing shortages. Of these 240 municipalities, 221 argue that they specifically have a shortage of housing for refugees. As Sahlin (2004) noted, refugees were seldom part of the mainstream discourse on homelessness. As we shall see in the coming sections, they are now at the very centre of the debate.

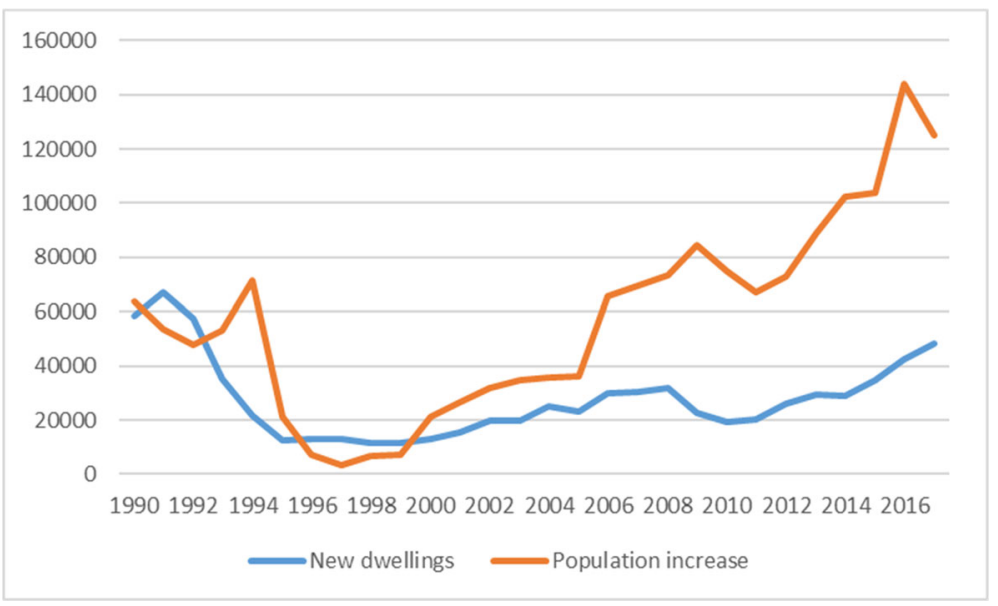

Fig. 1 New dwellings and population increase 1990-2016. Source: Statistics Sweden and own adaptations. 


\section{The Governance of Refugee Housing in Sweden 1985-2019}

Here we briefly describe the historical developments of housing (settlement) policies for refugees, ending with a description of the current state of affairs. Figure 2 provides an overview of the most important changes in housing policies for refugees, starting from the 1985 reform when the state handed over practical responsibilities for refugee integration to local municipalities.

The state's policy goals for the housing and dispersal of refugees has changed over time. A general aim to counteract ethnic segregation and avoid ethnic clustering has been present since the 1980s and continues today. As we show in this section, new housing and settlement policies are motivated by an additional rationale to 'spread the burden' and increase settlement capacity.

The first policy for the dispersal of asylum-seekers and refugees across the country was the 1985 so-called 'whole of Sweden' strategy (Prop. 1983/84:124). The idea was to counteract concentration in urban areas and increase the solidarity between local governments. The new policy was a response to complaints from some municipalities which demanded an increased state responsibility for geographical dispersal and economic costs. The solution was to introduce two policy instruments that remained in some form up until the 2016 Settlement Law. The number of refugees which a municipality would accept was based on voluntary agreements between the state agency (the Migration Board) and municipalities. Civil servants were employed both to persuade municipalities to enter agreements and often to negotiate individual settlement cases with those who signed the agreements. The instrument of persuasion was complemented with economic instruments. The state compensated municipalities for any social assistance during the reception year and three additional years. Municipalities also received a one-off compensation payment for every refugee they accepted. With this policy, a principle was established that refugee reception is a local responsibility, supported by state funding. Even though the formal responsibilities at this time

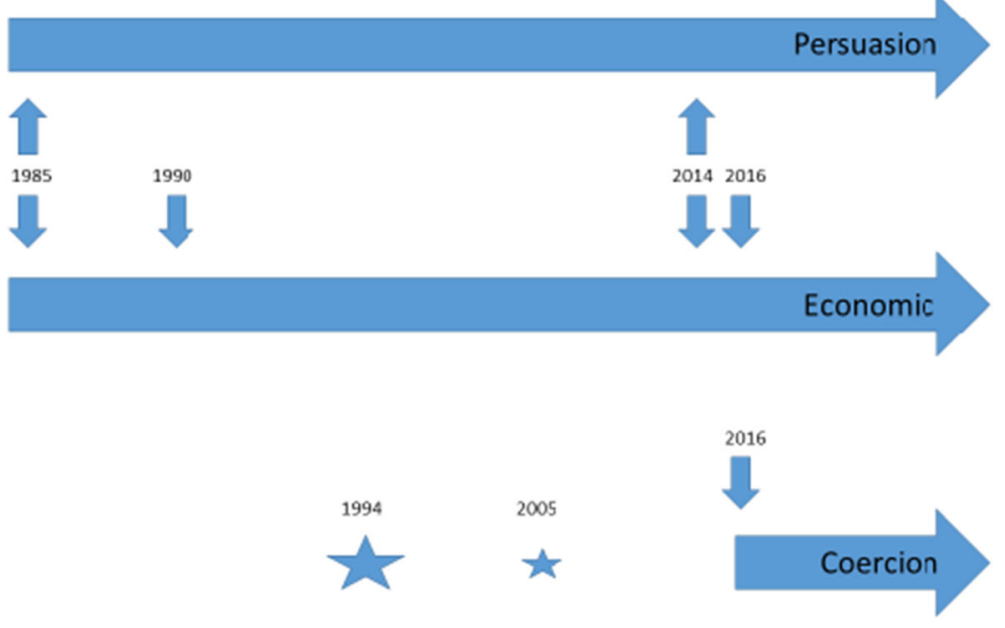

Fig. 2 Governance of Housing for Refugees (and Asylum-Seekers) 
shifted from the state to local municipalities, it can be interpreted as a first attempt by the government to steer housing for refugees by using economic instruments.

Over the years, economic instruments - supported by normative instruments have been the main steering strategy of central governments. A first change in economic compensation for municipalities occurred in 1990 (Ordinance, 1990:927). Instead of applying for state compensation based on actual costs, all municipalities with an agreement received a basic compensation of five base-price amounts per year. The municipality also receives a flat-rate allowance for each refugee. The goal of this new economic compensation was to reduce administration and increase the economic incentives for local governments to speed up the economic integration of refugees. The economic compensation is supposed to cover the municipality's costs for refugees' reception and practical assistance in connection with residence, schools, education in Swedish, preschool, social orientation, interpretation and other activities. In later years, temporary increases in economic compensation have been used to persuade municipalities to sign housing agreements with state agencies, for example in relation to the 2005 refugee amnesty (2005/06:SfU5).

A law that is hard to define in terms of steering was introduced in 1994 (Act 1994:137) in response to an increasing number of asylum-seekers during the second half of the 1980s and historically high levels during the Yugoslavian civil war in the early 1990s. Asylum-seekers were now encouraged to find their own accommodation during the asylum process, receiving a housing allowance to cover part of the rent. The reform was motivated by two arguments: to reduce the costs for the reception of asylum-seekers and to reduce social isolation during the waiting period.

Even though the law did not directly involve refugees, the freedom for asylumseekers to settle outside state reception centres did have consequences for municipalities and their ability to control the settlement of refugees. The deregulation of the requirement for asylum-seekers to stay in state reception centres relieved the pressure on the state asylum system. A secondary effect was that the capacity for refugee reception also greatly increased. Those asylum-seekers who lived in their own accommodation could now settle as refugees in the municipality where they lived as asylumseekers. Thus, refugees settled outside the system of voluntary agreements between the state and individual municipalities. However, the state still compensated municipalities economically. After complaints from some municipalities with a high number of asylum-seekers living in their own accommodation, the extra economic housing allowance was abolished in 2005 (Prop., 2004/05:28). The aim was that fewer asylum-seekers would choose to reside in their own accommodation during the asylum period. This reform did, however, have little impact on asylum-seekers' choice of housing.

As the housing shortage became more severe in the middle of the first decade of the 2000 s, the goal to reduce ethnic segregation took a backseat to allow for efforts to ensure an overall housing capacity for refugee settlement. Nevertheless, in the period between 2010 and 2014, about $70 \%$ of refugees and asylum-seekers settled themselves without help from state agencies. During this period, around 8000 people each year needed help from the Migration Board to find housing (DS, 2015:33) and thus relied on the voluntary agreements between the state and local municipalities. At this time, coercive measures to force municipalities to settle refugees were not considered possible due to the Municipality Act that protects the autonomy of local governments. 
Campaigns to persuade municipalities to accept refugees have been ongoing and have intensified over the years. In 2014, the government appointed two coordinators to ensure the increased municipal refugee reception (Regeringskansliet, 2014). Their mission involved motivating more municipalities to increase their refugee reception and presenting opportunities for refugee reception in municipalities that only accepted a few (or no) refugees. Another recurring strategy was to make both one off reimburses and more permanent increase the state funding for refugee settlement in local municipalities. In 2014 an extra economic incentive to settle refugees was introduced. The Migration Board paid compensation to the 145 municipalities that received the most refugees in relation to their population. In 2015, extra economic compensation was given to municipalities for each person settled under voluntary agreements.

Despite many efforts from the government to increase the refugee settlement capacity, the number of persons granted asylum who were waiting for housing in asylum reception centres grew — in October 2015, 10,000 were waiting (Prop. 2015/ 16:54). The government therefore proposed a law that forced municipalities to settle refugees, the so-called Settlement Law. In the government investigation (DS, 2015:33) before the bill, they dwelt on the reasons for the new law. The political will to continue a 'generous' asylum policy creates a need to increase the capacity for refugee settlement in municipalities. The current system, with voluntary agreements, lacks the ability to ensure the capacity to settle refugees. The proposal found support in parliament and came into force on 1 March 2016. At the same time, the economic compensation per settled refugee was increased permanently by $50 \%$ from 83,100 ( 8204 Euro) to 125,000 (12,340 Euro) (Prop. 2015/16:1).

Under the current system, municipalities receive economic compensation for five main categories of migrant (see Table 1), who are all seen as part of the refugee reception system since they are eligible for participation in an introduction programme. Former asylum-seekers who rented private accommodation during the asylum process and the families of refugees are not included in the 2016 Settlement Law. From the state's point of view, they are responsible for settling themselves. Resettled and former asylum-seekers who stayed in reception centres are, however, covered in the law, according to which municipalities are obliged to arrange reception for a designated number. First, the Migration Board calculates regional quotas based on labour-market conditions, the size of the region and the number of asylum-seekers and refugees in each locality. The Settlement Act assigned a new role to Regional County Administrative Boards across the country. While the Migration Agency decides on the number of assigned refugees for each region, it is the County Administrative Board that decides on the number for each municipality. While this can be viewed as a multilevel structure of governance, all the implementation remains with the municipalities. Yet it is within the interests of the County Administrative Board to oversee the situation so that all refugees can settle in their assigned municipalities. As we show in the next part of the article, these different categories play an important role for refugee housing provision at the local level. Since 2020 a revision of the law on private accommodation (Prop. 2019/ 20:10) for asylum-seekers was implemented in a further attempt to prevent them finding housing in 'socio-economically exposed' areas in 32 Swedish municipalities. Asylum-seekers who settle in areas established by the Swedish Migration Board will lose their economic support. During the spring of 2020, municipalities had the opportunity to define such areas for themselves. Eleven municipalities chose to report the 
whole municipality as a socio-economically exposed area - thus not in accordance with the specific areas that were intended in the government's revision of the 'own accommodation' regulation. Despite the many years of criticism from some municipalities, the revision of the law should not be understood as a result of this but, rather, in relation to the introduction of the Settlement Law. Asylum-seekers who settle in a municipality will automatically be settled there when they receive their residence permit. Thus, if there is no control over the settlement of asylum-seekers then the Settlement Law is, in effect, a less-powerful tool for control.

\section{Local Refugee Housing Solutions: Reactions to State Steering}

In this second part of the article, we look at housing policies and solutions for refugees at the local level which, in many ways, are played out as a reaction to state policies and regulations. Our main case is the city of Malmö, although the municipality of Eslöv is also used to give further perspectives. Malmö is the third-largest city in Sweden with 340,000 inhabitants, a post-industrial city situated just on the border with Denmark. Eslöv, on the other hand, is a small rural municipality with some industrial production and within commuting distance of Malmö. Both municipalities are located in the Scania region in southern Sweden.

Malmö is known to be one of the loudest voices against the 1994 law that made it possible for asylum-seekers to find their own accommodation during the asylum application (Myrberg, 2017). Since asylum-seekers could stay on in the municipality after a positive decision on their asylum application, the 1994 law was a form of deregulation that made it more difficult for local municipalities to control the inflow of refugees. Already before the deregulation, the political leadership in Malmö had complained about secondary movements to Malmö (Slavnic, 2000). Since there were empty apartments to be had, especially among private landlords, refugees left the smaller municipalities to settle in Malmö. Other refugees with residence permits left reception centres of their own accord and found private accommodation relatively easy. This meant that Malmö received more refugees (4859 in 1994) than was stipulated in the agreement between Malmö and the Migration Board (950). The City of Malmö tried to stop private landlords from renting out apartments to refugees but largely failed,

Table 1 Refugee Settlement in 2018

\begin{tabular}{ll}
\hline Category & Number \\
\hline Resettled & 5028 \\
Former asylum-seeker, who stayed in reception centres & 11,068 \\
Former asylum-seeker, who stayed in own accommodation & 7859 \\
Family to refugees & 16,562 \\
Other & 3699 \\
Total & 44,216 \\
\hline
\end{tabular}

Source: Migration Board 
since there were huge profits to be made from filling empty houses with new tenants (Slavnic, 2000).

In the middle of this conflict and the failed efforts by the political leadership in Malmö to control the inflow of refugees with residence permits, asylum-seekers became free to move to apartments outside reception centres. From Malmö's perspective, the EBO created unpredictability in the numbers of refugees and forced the city to shoulder a heavier burden.

Because of this and, together with other cities who feel that they are in the same situation, Malmö has lobbied the government for a change in the law on asylum reception. The Mayor of Malmö, Ilmar Reepalu, became the foremost symbol of the resistance against free settlement for asylum-seekers. In 2004, he suggested a five-year break from refugee reception. Eventually, all political parties in Malmö agreed to make another demand to the government - the abolition of state housing support for asylum-seekers in private accommodation (Malmö Stad, 2004). In 2010, a year before he retired as mayor, Reepalu sent his last letter to the government requesting an overhaul of the EBO legislation (Fjellman, 2012). In the consultation ahead of the 2016 settlement law, Malmö supported the motion to force municipalities to settle refugees in order to increase the reception capacity (Malmö Stad, 2015). They still, however, requested changes to the asylum reception system and complained about the lack of state funding and increasing problems with homelessness.

The local focus in Malmö on self-settled asylum-seekers, is, however somewhat misleading because, in reality, there has not only been a resistance to asylum-seekers in private accommodation (EBO). Malmö has not had a voluntary agreement with the state to receive refugees for many years. From the city's perspective, this means that those who do settle in Malmö — former asylum-seekers in EBO, refugees from reception centres and persons arriving for family reunification — are considered as self-settled. The City of Malmö did receive state funding for their settlement but, since they moved to the city outside of the organised settlement process, there was no municipal organisation in relation to housing for refugees prior to settlement law in 2016. Thus, before 2016, Malmö did not differ between persons who had found their own accommodation during the asylum process and those who had stayed in stateprovided accommodation (anläggningsbostäder or ABO). Refugees found their accommodation through their own means or became homeless and subject to Social Services.

As a contrast, Eslöv municipality chose another strategy. They had had voluntary agreements with the state for many years and an organisation to provide housing. However, refugees arriving from Own Accommodation were not included in that reception.

\section{Reactions to the 2016 Settlement Law and the Local Organisation of Refugee Housing}

The Settlement Law of 2016 has had a big impact on the distribution of refugees between municipalities (Osanami Törngren and Emilsson, 2018). Municipalities who, previously, had a below-average number of settled refugees now became forced to accept a designated and higher number. The law affected a city like Malmö less 
because, already before the law, the city had received a high enough number of selfsettled refugees. For Malmö, the new law was seen as a relief as it forced other municipalities to house refugees that Malmö otherwise feared would end up on their doorstep. Nevertheless, the $10 \%$ of the refugees assigned according to the Settlement Law (see Table 2) have created many organisational and administrative reactions in Malmö too.

Today, Malmö has a clear policy towards refugee settlement. The city states that it does not offer self-settled refugees any help - these latter need to compete on the housing market with everyone else. When the Settlement Law was enacted in 2016, the city had to create a new unit since there were no existing organisations for providing housing for refugees. These organisations make an estimation of the need for housing units and place an order with the city's housing unit. For those who are settled according to the Settlement Law, only temporary solutions are offered. Solutions vary and can range from rented apartments to locations in residential modules or group homes. The municipal housing company is a partner in this and most are placed in their housing stock.

The Settlement Law only stated that municipalities are obliged to accept a specific number of refugees. Since the refugees follow an introduction programme in the first two years, some municipalities, including Lidingö in Stockholm, claimed that the Settlement Law should also be limited to the same time frame. Eventually, Lidingö won a court case and found support for their interpretation of the law (Kammarrätten i Stockholm, 2018). Malmö has chosen a four-year limit for their housing contracts. In most cases, Malmö rents the apartments and the refugee sublets from the municipality. Any person who sublets for four years has an occupancy right to a first-hand contract, which is why Malmö has chosen four years as the time limit for the contracts. Some of the contracts are shorter as they sometimes depend on contracts with private housing companies. Malmö does not offer or have any strategies to arrange permanent housing solutions - such as first-hand tenant contracts. However, there is a support programme designed to educate refugees in how to look for housing.

Eslöv uses a somewhat different strategy. It relies on negotiations with private housing companies and has no organised cooperation with the municipal housing company. Prior to the Settlement Law in 2016, the town had an agreement to receive refugees and a special unit working to organise housing, with the aim of providing permanent solutions, either directly or by transforming short-contract housing into permanent accommodation. After 2016, those who are settled accordingly sign a second-hand contract for accommodation that the municipality is renting from housing

Table 2 Number of assigned and received refugees in 2018 in Eslöv, Malmö, the Scania region and Sweden

\begin{tabular}{lllll}
\hline Municipality & Population & $\begin{array}{l}\text { Assignments according to the Settlement } \\
\text { Act }\end{array}$ & $\begin{array}{l}\text { Refugee reception in } \\
\text { total }\end{array}$ & $\begin{array}{l}\text { Foreign- } \\
\text { born }\end{array}$ \\
\hline Eslöv & 33,557 & $63(0.188)$ & $164(0.487)$ & 18.0 \\
Malmö & 339,313 & $155(0.046)$ & $1488(0.438)$ & 34.0 \\
Scania & $1,362,164$ & $1800(0.132)$ & $6231(0.457)$ & 22.0 \\
Sweden & $10,230,185$ & $15,200(0.149)$ & $44,217(0.432)$ & 19.0 \\
\hline
\end{tabular}

Source: Public data from the Swedish Migration Agency and Statistics Sweden 
companies. In contrast to Malmö, their housing unit does have a goal of finding permanent solutions for the refugees. This is, however, an ongoing process, since most refugees start with temporary housing solutions. As in Malmö, they also use group homes or corridor housing, particularly for men without their families in Sweden. Corridor housing is also the form of housing that, according to our interviews with refugees, is connected to more-negative experiences. There are restrictions on bringing home friends and common spaces such as the kitchen, bathroom and living room might be arenas for conflict.

Another issue brought up during interviews with both municipalities is the difficulties of finding housing for families with many children. In some cases, villas are bought or rented and former pre-schools are rebuilt to house families. In addition to the many different types of accommodation and length of contract, another issue is the variation of renting costs. Assigned housing can charge very different rents and the refugees have few possibilities to affect this by changing their accommodation. In Malmö, there are a few ways in which a refugee accepted under the Settlement Law can apply for a change in his/her housing situation. Municipal officers told us that some large families in apartments which are simply too small and LGBTQ-related cases have been given alternative accommodation.

Temporary housing solutions for refugees have become more common over time. Reports show that about half of the municipalities offer permanent housing for refugees (Boverket, 2019; Länsstyrelsen, 2018). In metropolitan regions, almost no municipality offers permanent contracts. In the Scania region, 16 of the 29 municipalities only offer temporary contracts, while only four offer permanent contracts to all refugees (Länsstyrelsen, 2018). Temporary accommodation such as shared apartments, corridor accommodation and modules - solutions that were previously only used by asylumseekers - are now standard in many municipalities. From interviews with refugees, we know that temporary solutions are not favourable. Some of the interviewees had actively turned down temporary offers partly in search for a more durable solution and also the possibility of choosing the location. One person, a young man without children had found an accommodation through his own social network. The major reason for him to organise his own accommodation was fear of criminality and difficulties to integrate into society. Another person, a young woman with small children wanted to avoid the accommodation provided by the city as she considered it as insecure for the children. As a result of her rejection to the accommodation organised by the city, she lived with her family in a house for homeless persons that Malmö rent in a neighbouring community. In the interviews with refugees who had access to their own apartment with the possibility to turn the contract into a permanent one, there was general satisfaction regarding accommodation.

Family reunification is another issue that is relevant in relation to housing for refugees. In Malmö, the municipality does not take any special responsibility for their accommodation. The result is overcrowding or even homelessness. Eslöv's approach is slightly different. Although a person cannot claim housing for family members arriving after his/her settlement, the municipality tries to find solutions in order to avoid homelessness. 


\section{Refugee Housing and Homelessness}

A majority of the refugees who arrive in Malmö do so outside the system of organised settlement. The political leadership has decided to not offer them any targeted housing solutions. Still, most are registered as residents in Malmö since they arrived there as asylum-seekers. This decision, together with severe housing shortages, has led to increasing problems of homelessness (Fig. 3).

The city distinguishes between structural and social homelessness. Its website defines structural homelessness as persons without the economic means to enter the usual housing market and social homelessness as persons with substance abuse and/or mental problems who need support from Social Services.

Structural homelessness in Malmö has grown in recent years - in fact, it increased 3.5 times between 2008 and 2017. Newly arrived immigrants are today a majority among the homeless. In 2017 in Malmö, 1752 persons were suffering from acute homelessness and over 1000 children were homeless. Significantly, among the homeless, there is an increase of foreigners with less than three years of residence in Sweden. They are offered short-term solutions through hotels or bed-and-breakfast accommodation (Malmö Stad, 2018). Only the municipal housing company and a few private housing agencies accept tenants who receive economic support. The situation in Eslöv is different; in an interview on 21 August 2018 with a representative of the municipality, it was confirmed that there are no people who are homeless in terms of sleeping on the streets and there is no homelessness among the assigned and resettled refugees.

There is a strict administrative division between the organisation of housing for homeless persons and the organisation of housing for refugees. A specific housing unit for the reception of assigned refugees was created during the municipal reorganisation in 2017 within the Welfare Department for Special Needs (Sociala resursförvaltningen). This unit arranges and maintains accommodation facilities for assigned and resettled refugees. As one informant, an official at the City of Malmö, argued:

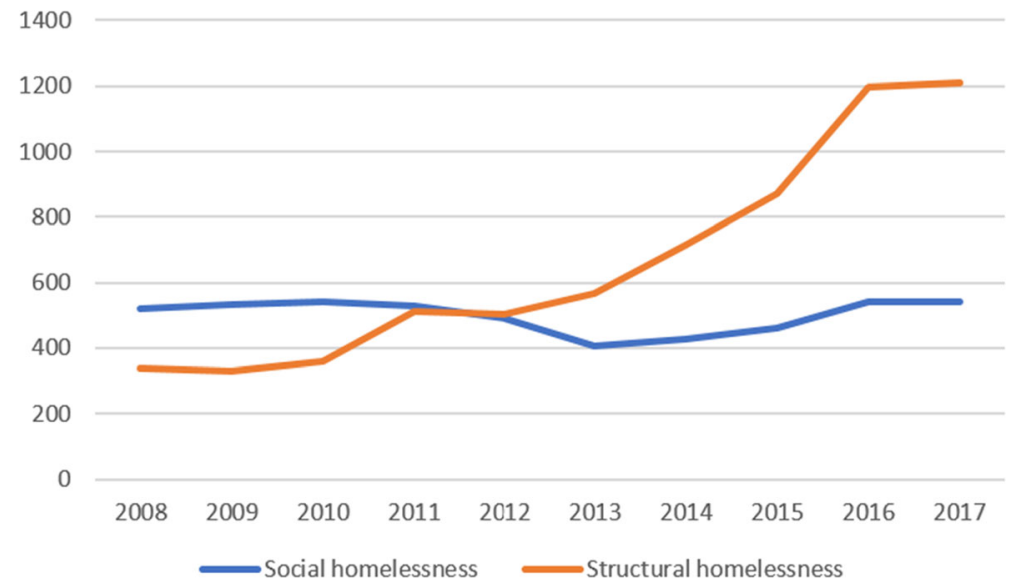

Fig. 3 Number of Homeless Individuals in Malmö 2009-2017. Source: City Office, City of Malmö 
We need to keep this (the organisation of housing for refugees and the provision of support against homelessness) as two separate tracks. There is no end to homelessness, there are no solutions. But in relation to the law we must organise housing for a specific number of refugees. ... but it is unavoidable that we compete for the same apartments. There are only so many apartments. ... To become homeless is not only a question of the lack of housing, you need to have a specific problem that prevents you from finding housing on your own. It is not enough to be newly arrived in Sweden, to not know the language or to lack the money. To live in Malmö is not a right in itself.

The above quote eloquently describes how administrative classifications determine what kind of housing support a refugee can expect.

Another officer in Malmö explained in an interview on 21 June of that year that the municipality must separate the management of accommodation for assigned and resettled refugees from the management of homelessness, since the problem of homelessness is infinite. The tasks made mandatory by the Settlement Act are, since the court ruling, interpreted as limited in time, while the problem of homelessness has no end it (interview, 23 August). This means that those refugees who are defined in the Settlement Law are provided with up to four years of temporary housing solutions. Other refugees are not entitled to anything, not even to become homeless in the eyes of the Social Services. In the summer of 2019, the political leadership decided on an even harsher interpretation of the Social Services Act whereby temporary housing solutions were also restricted for those who are structurally homeless. They now have no right to benefit from assistance in a homeless situation other than as an emergency, basically shelter or 'a roof over one's head'.

\section{Concluding Analysis}

Sweden has experienced a relatively high refugee reception rate in recent decades, with a spike during the so-called refugee crisis in 2015/16. In the last 10 years (2009-2018) 375,000 persons - nearly $4 \%$ of the population - were granted asylum or reunited with family members. At the same time, most municipalities experience severe housing shortages. While the state government is responsible for controlling immigration, it is a local government responsibility to provide accessible housing for its residents.

Over the years the state has experimented with different governance techniques and policy instruments to solve the settlement of refugees. The ambitions from the state have been to secure local capacity to settle refugees, and also to 'spread the burden' between municipalities. In order to understand these developments, we apply a multilevel governance analytical framework inspired by Etzioni (1975), where the state can use three different instruments to realise their policy ambitions: coercive, economic and persuasive. Starting from 1985, the state used persuasion and economic instruments. Voluntary agreements were made between the state and local governments where the municipalities received economic compensation when settling refugees. This arrangement meant that local municipalities had some control over the inflow. However, since most cities had empty apartments, some refugees found accommodation through friends and contacts. Malmö, with a large community from the former Yugoslavia, 
saw considerable numbers of refugees moving into the empty housing stock in the mid1990s. Local efforts to curb the inflow failed.

In the aftermath of the refugee immigration flow during the civil war in Yugoslavia, it became obvious that the Swedish reception system lacked sufficient capacity. It was difficult and expensive for the Migration Board to house all asylum-seekers, especially since the numbers fluctuated over the years. Asylum-seekers who received residence permits also got stuck in reception centres since the voluntary agreements with the municipalities did not deliver enough capacity. To relieve the pressure on the asylum reception system, the state decided in 1994 to de-regulate. Asylum-seekers were now free to find accommodation on their own while they waited for a decision, and after a positive decision became registered in the municipality where they had stayed during the asylum process. This was a form of coercive decentralisation that did increase settlement capacity at the expense of local municipalities.

In 2012, the number of refugees who needed settlement started to increase again, coinciding with a growing housing shortage in many municipalities. In order to increase the settlement capacity, the state further tried to persuade local governments, as well as experimenting with higher and newer systems of economic compensation. When these efforts were not sufficient, the parliament supported the Settlement Act, in force since 2016. The Act makes it mandatory for municipalities to arrange accommodation for refugees assigned by the Migration Board. We can see that the state has used its powers to involve lower levels of government in line with their policy agenda, first by using persuasion and economic instruments and eventually coercive instruments to ensure compliance.

In many ways, the state has through coercive government instruments (de-regulation of housing for asylum seekers and mandatory refugee settlement) decentralised the responsibility of refugee settlement to local municipalities. Since these decisions are not accompanied by any regulations about, for instance, the kind of accommodation and its standards, its location, renting costs and length of rental contracts, its implementation varies considerably between municipalities. The reaction from the local level has often been to introduce new housing solutions that tends to undermine long-term strategies for accommodation, housing and integration. In this sense, the state government legitimises a fragmented and unfair reception system across the municipalities,

The fact that the Settlement Law only includes refugees who stayed at reception centres during the asylum process also tends to legitimise differential treatment for different categories. Those who are self-settled outside the organised settlement system and reunited families receive no help at all in Malmö and in many other municipalities. They are seen as part of the problem of structural homelessness and, since Sweden has no means tested social housing, they have to compete with everyone else on the crowded housing market.

This also further reveals the distinction between social and structural homelessness. Homelessness is not only growing but is also changing in character. The proportion of persons suffering from social homelessness is decreasing and the proportion of those affected by structural homelessness, where the majority are newly arrived refugees, is increasing. In many cases, this means that self-settled refugees and refugees with newly arrived family members, as well as individuals and families who have dropped out of the settlement system, can access no support. 
The Settlement Law is a particularistic law in the sense that it forces municipalities to arrange accommodation for a particular group of people. Hence, the implementation of the Settlement Act creates tension between, on the one hand, the accommodation management of refugees assigned according to the Settlement Law and, on the other, the management of accommodation for the homeless. In different municipalities, this tension is managed in a number of ways; yet, it would seem, the Settlement Act contributes to a fractioned service system within the municipalities. The coercive aspects of the settlement law contributed to changes in local housing policies to more temporary housing arrangements for refugees and to a differentiation of services between different categories of refugees. This is not unusual for particularistic solutions and cries out for a discussion about general solutions. It is indisputable that the implementation of the Settlement Act is only partly a result of the refugee immigration flows in 2015; it is also a consequence of structural homelessness.

It is our view that housing and the Settlement Act should be discussed from the perspective of general housing policy and housing market dynamics, instead of particular groups in precarious housing situations. In most cities in Sweden, housing is a scarce and valued commodity, where rental controls contribute to a higher demand than supply. Local governments find it difficult to defend previous long-term housing solutions for refugees when the local population compete for the same public goods. The results of increasing the refugee settlement capacity through coercive measures is, thus, creating new local policies and administrative categorisations that unfortunately are pitting different vulnerable groups against each other. We argue that, although the new legislation has created a nationally more even dispersal of refugees, this is a further break away from what has been a core issue in Swedish integration policy - equality.

Funding Open access funding provided by Halmstad University. This work was supported by GLIMER 'Governance and Local Integration of Migrants and Europe's Refugees', a Joint Programme Initiative (JPI) under the H2020 and was selected for funding by ERA-NET Cofund Smart Urban Futures and the Swedish part was funded by FORMAS (The Swedish Research Council for Environment, Agricultural Sciences and Spatial Planning). It was additionally funded by NIEM 'National Integration Evaluation Mechanism. Measuring and improving integration of beneficiaries of international protection' Funded by the Asylum, Migration and Integration Fund (AMIF).

Open Access This article is licensed under a Creative Commons Attribution 4.0 International License, which permits use, sharing, adaptation, distribution and reproduction in any medium or format, as long as you give appropriate credit to the original author(s) and the source, provide a link to the Creative Commons licence, and indicate if changes were made. The images or other third party material in this article are included in the article's Creative Commons licence, unless indicated otherwise in a credit line to the material. If material is not included in the article's Creative Commons licence and your intended use is not permitted by statutory regulation or exceeds the permitted use, you will need to obtain permission directly from the copyright holder. To view a copy of this licence, visit http://creativecommons.org/licenses/by/4.0/.

\section{References}

Aflaki, I. N., \& Freise, M. (2019). Challenging the welfare system and forcing policy innovation? unaccompanied asylum-seeking children in Sweden and Germany. Journal of Refugee Studies, fez036. https://doi. org/10.1093/jrs/fez036. 
Andersson, R. (2003). Settlement dispersal of immigrants and refugees in Europe: Policy and outcomes. Vancouver Centre of Excellence.

Åslund, O., \& Rooth, D. O. (2007). Do when and where matter? Initial labour market conditions and immigrant earnings. The Economic Journal, 117(518), 422-448.

Bengtsson, B. (Ed.). (2013). Varför så olika? Nordisk bostadspolitik I jämförande nordiskt ljus (2nd ed.). Egalite.

Bevelander, P., Mata, F., \& Pendakur, R. (2019). Housing policy and employment outcomes for refugees. International Migration, 57(3), 134-154.

Borevi, K., \& Bengtsson, B. (2015). The tension between choice and need in the housing of newcomers: A theoretical framework and an application on Scandinavian settlement policies. Urban Studies, 52(14), 2599-2615.

Boverket. (2019). Bostadsmarknadsenkäten 2019. Boverket.

Dekker, R., Emilsson, H., Krieger, B., \& Scholten, P. (2015). A local dimension of integration policies? A comparative study of Berlin, Malmö, and Rotterdam. International Migration Review, 49(3), 633-658.

Edin, P., Fredriksson, P., \& Åslund, O. (2003). Ethnic enclaves and the economic success of immigrants: Evidence from a natural experiment. The Quarterly Journal of Economics, 118(1), 329-357.

Emilsson, H. (2015). A national turn of local integration policy: Multi-level governance dynamics in Denmark and Sweden. Comparative Migration Studies, 3(7), 1-17.

Etzioni, A. (1975). A comparative analysis of complex organizations: On power, involvement, and their correlates. The Free Press.

Fjellman, E. (2012). Reepalu kör sitt eget race, Sydsvenskan, 25 March.

Granath Hansson, A., \& Lundgren, B. (2019). Defining social housing: A discussion on the suitable criteria, Housing. Theory and Society, 36(2), 149-166.

Grander, M. (2018). For the benefit of everyone? Explaining the significance of Swedish public housing for urban housing inequality. Malmö: Malmö University: $\mathrm{PhD}$ thesis.

Hamann, U., \& El-Kayed, N. (2018). Refugees' access to housing and residency in German cities: internal border regimes and their local variations. Social Inclusion, 6(1), 135-146.

Integration Board. (2001). Rapport Integration 2001. Integrationsverket.

Integration Board. (2003). Rapport Integration 2002. Integrationsverket.

Kammarrätten i Stockholm. (2018). Mål nr 4155-18. Kammarrätten.

Larsen, B. R. (2011). Becoming part of welfare Scandinavia: Integration through the spatial dispersal of newly arrived refugees in Denmark. Journal of Ethnic and Migration Studies, 37(2), 333-350.

Länsstyrelsen. (2018). Mottagande och etablering av nyanlända 2018. Länsstyrelsen.

Stad, M. (2004). Välfärd för alla - förslag, Kommunstyrelsen. Malmö Stad.

Stad, M. (2015). Remiss från Arbetsmarknadsdepartementet: Promemoria med förslag om ett gemensamt ansvar för mottagande av nyanlända, Dnr. STK-2015-777. Malmö Stad.

Malmö Stad. (2018). Kartläggning av hemlösheten och insatser för hemlösa 2017. Malmö Stad.

Myrberg, G. (2017). Local challenges and national concerns: Municipal-level responses to national refugee settlement policies in Denmark and Sweden. International Review of Administrative Sciences, 83(2), 322339.

National Board of Housing, Building and Planning. (2019). Bostadsmarknadsenkäten 2019. Boverket.

Osanami Törngren, S., \& Emilsson, H. (2018). (2018). Nationell Rapport: Sverige. Malmö University, NIEM National Report.

Porter, D. O., \& Olsen, E. A. (1976). Some critical issues in government centralization and decentralization. Public Administration Review, 36(1), 72-84.

Sahlin, I. (2004). Central state and homelessness policies in Sweden: New ways of governing. European Journal of Housing Policy, 4(3), 345-367.

Slavnic, Z. (2000). Ekonomisk åtstramning och flyktingmottagning. Sociologisk Forskning, 37(2), 66-93.

Spehar, A. (2014). Svensk migrationspolitik och EU medlemskap. In L. Berg \& R. Lindahl (Eds.), Förhoppningar och farhågor: Sveriges 20 första år $i$ EU (pp. 145-164). University of Gothenburg.

Stewart, E. S. (2011). UK dispersal policy and onward migration: Mapping the current state of knowledge. Journal of Refugee Studies, 25(1), 25-49.

Vedung, E. (2009). Utvärdering i politik och förvaltning. Studentlitteratur.

Zenou, Y., Åslund, O., \& Östh, J. (2006). Hur viktig är närheten till jobb för chanserna på arbetsmarknaden? Ekonomisk Debatt, 34(6), 31-42. 


\section{Bills and Government Documents}

Act on Reception of Asylum Seekers (1994:137)

Act on Municipal Housing Responsibility (2000:1383)

DS 2015:33 Ett gemensamt ansvar för mottagande av nyanlända

Municipal Act (1991:900)

Ordinance 1990:927 om statlig ersättning för flyktingmottagande m.m.

Prop. 2004/05:28 Bostadsersättning för asylsökande.

Prop. 2015/16:1 Budgetpropositionen för 2016.

Prop. 2015/16:54 Ett gemensamt ansvar för mottagande av nyanlända.

Prop. 2019/20:10 Ett social hållbart eget boende för asylsökande.

Regeringskansliet (2014). Slutrapport: Regeringens samordnare för kommunalt flyktingmottagande, Dnr A2014/232/IU.

Social Services Act (2001:453)

2005/06:SfU5 Socialförsäkringsutskottets betänkande. Ny prövning av avvisnings- och utvisningsbeslut.

Publisher's Note Springer Nature remains neutral with regard to jurisdictional claims in published maps and institutional affiliations. 